PEOPLE: International Journal of Social Sciences

ISSN 2454-5899

Odit-Dookhan et al., 2022

Volume 7 Issue 3, pp. 208-229

Received: $1^{\text {st }}$ June, 2021

Revised: 28 $8^{\text {th }}$ October, 2021; 19th January, 2022

Accepted: 09th February, 2022

Date of Publication: 10 th February, 2022

DOI- https://doi.org/10.20319/pijss.2022.73.208229

This paper can be cited as: Odit-Dookhan, K., Chittoo, H. B., Armoogum, V., Odit, M. P., Seebaluck, V., Narsoo, J. (2022). Exploring Work Placement Experience: Case of the University of Technology, Mauritius. PEOPLE: International Journal of Social Sciences, 7(3), 208-229.

This work is licensed under the Creative Commons Attribution-NonCommercial 4.0 International License. To view a copy of this license, visit http://creativecommons.org/licenses/by-nc/4.0/ or send a letter to Creative Commons, PO Box 1866, Mountain View, CA 94042, USA.

\title{
EXPLORING WORK PLACEMENT EXPERIENCE: CASE OF THE UNIVERSITY OF TECHNOLOGY, MAURITIUS.
}

\section{Kiran Odit-Dookhan}

Lecturer, Department of Accounting, Finance and Economics, School of Business, Management and Finance, University of Technology, Mauritius, La Tour Koenig, Republic of Mauritius koditdookhan@umail.utm.ac.mu

\section{Hemant Birandranath Chittoo}

Associate Professor (Dr), Department of Accounting, Finance and Economics, School of Business, Management and Finance, University of Technology, Mauritius, La Tour Koenig,

Republic of Mauritius

hchittoo@umail.utm.ac.mu

\section{Vinaye Armoogum}

Associate Professor (Dr), Department of Industrial Systems Engineering, School of Innovative Technologies and Engineering, University of Technology, Mauritius, La Tour Koenig, Republic of Mauritius varmoogum@umail.utm.ac.mu

\section{Mohun Prasadsing Odit}

Senior Lecturer(Dr), Department of Accounting, Finance and Economics, School of Business, Management and Finance, University of Technology, Mauritius, La Tour Koenig, Republic of Mauritius

aodit@umail.utm.ac.mu 


\title{
Vanessa Seebaluck
}

Lecturer, Department of Tourism Leisure and Services, School of Sustainable Development and Tourism, University of Technology, Mauritius, La Tour Koenig, Republic of Mauritius vseebaluck@umail.utm.ac.mu

\section{J. Narsoo}

Senior Lecturer (Dr), Department of Industrial Systems Engineering, School of Innovative Technologies and Engineering, University of Technology, Mauritius, La Tour Koenig, Republic of Mauritius

jnarsoo@umail.utm.ac.mu

\begin{abstract}
The inclusion of job training and learning has recently been acknowledged as not only a key element of organizational initiatives to enhance learners' job readiness, but even as an organizational initiative to establish themselves in the marketable global education industry (Tran \& Soejatminah, 2016). University students' work-readiness continue to be a significant issue, with Mauritian industries lamenting a lack of soft skills and real-life experiences deemed necessary for recruitment. The University of Technology, Mauritius (UTM) has completely adopted the Work Placement principles since 2014 to extend numerous options to its learners to offer relevant work experiences. The present study aims at exploring the role of the Work Placement experience among the students studying at the UTM. A survey was conducted using an online questionnaire among 230 participants to measure soft-skill development. Before and after the internship, descriptive statistics such as means, standard deviations, and varying scores were investigated using SPSS. The results reveal that students have a positive attitude toward the acquired skills and abilities through Work Placement. The majority of the students asserted that through their Work Placement experiences, they have acquired important soft skills and have become excellent team players and good communicators.
\end{abstract}

\section{Keywords:}

Work Placement, Soft Skills, Work Experience, Employability of Graduates

\section{Introduction}

Institutions are emphasizing the inclusion of theories and practical work experience, as well as the enhancement of learners' competencies, to improve the employability of graduates. The advantages of the learning experience aimed at streamlining observation on academic research and incorporating theory with practice involve improved job readiness, self-efficiency, instinctive 
abilities, and collaboration. (Jackson, 2014; Orrell, 2011; Patrick et al., 2008). Patrick et al. (2008) developed one of the most commonly cited definitions of this learning process, linking it to "a range of approaches and strategies that integrate theory with the practice of work within a purposefully designed curriculum."

Mauritius, as a Small Island Developing State, is constrained by a lack of natural resources, resulting in a strong reliance on human capital (UNDESA Division for Sustainable Development, 2014). Nonetheless, despite numerous job openings, graduate employment and work readiness remain a pressing issue, with Mauritian industries lamenting a lack of soft skills and real-life experiences deemed necessary for staffing (Business Magazine, 2016). Work Placement is a critical tool used by academic institutions to supply a skilled workforce by providing opportunities for learners for the development or enhancement of both disciplinary expertise and soft skills that employers highly value. (Billett, 2009; Choy \& Delahaye, 2016; Jackson, 2015; Smith, 2012; Smith et al., 2014).

The University of Technology, Mauritius (UTM) has fully embraced the Work Placement component since 2014 to provide its students with a variety of opportunities to facilitate transitioning from higher education institutions to work to enhance productivity outcomes for employers and the industry. This research aims to look into the role of the Work Placement experience among the students studying at the UTM and to identify the factors, which influence the satisfaction level of the students.

\section{Literature Review}

Work placement is an effective pedagogical approach for increasing career development skills in students by orienting them in real-world ideologies, frameworks, and practices. Academic institutions are focusing primarily on how Work Placement can be addressed across a degree to engage learners in various activities of Work Placement to put supervisory knowledge and expertise to use. The evolution of Work Placement typologies over the last decade represents a move away from a narrow conception of Work Placement as 'Work Placements' to a much broader and widening lens of Work Placement. However, models of placement often seem to be the major source of Work Placement that can be easily identified within the framework of a degree structure whereas the non-placement varieties of Work Placement continue to be less noticeable. Work Placements whereby students undertake sustained time in a workplace with an industry partner, 
are historically seen as the dominant form of Work Placement and are often integrated within accredited degrees as a mandatory activity (Patrick et $a l$. 2009). These placement models, such as internships and co-ops, may be used as sandwich units (Work Placement after formal studies as part of degree) or capstones (unit in the final year of studies designed to integrate and apply to learn) and have been shown to have a significant impact on graduate employment outcomes (Silvia et al. 2018).

While the benefits of Work Placements are well established in the literature (Kramer \& Usher 2011; Smith et al. 2014), however, the extent to which students engage in their Work Placements varies. Similarly, Jorre de St Jorre \& Oliver (2017) explained that, even though educational institutions cannot assure learners job opportunities in their fields of expertise, Work Placements are believed to improve students' employment prospects by gaining skills, personality traits and proficiencies that maximize students' chances of finding or establishing challenging tasks. As a result, the consensus is that the degree to which learners can find work represents the degree of support they obtain from their institution (Jackson \& Wilton, 2017). On the other hand, employers want degree holders with knowledge and competencies that will help them integrate into the knowledge-based economic system (Walker \& Fongwa, 2017).

\subsection{The Benefits of Work Placement}

According to Taylor \& Govender (2017), "the notion that workplace experience enhances people's prospects of employment is widely accepted". The shortage of labour with the necessary skills has increased the popularity of Work Placement at universities, as the Work Placement component conduces to producing degree holders who would be more "work-ready" therefore, employable straightaway (Smith \& Worsfold, 2015).

\subsubsection{Benefits to the Students:}

- Gaining authentic, real-world experiences integrated with their theoretical knowledge

- Developing self-confidence and self-awareness

- Building professional networks for career development

- Developing an understanding of the relevant industry and prospects

- A possible opportunity for future employment

\subsubsection{Determinants of Work Placement Effectiveness}

Varieties of attributes have been proven to effectively assist graduates to understand the skills they are expected to have. While concepts like traits, attributes, and interpretations relate to 
an individual's capabilities. As stated by Law \& Watts (2003) and Watts (2006), employability skills consist of four elements, which are self-awareness abilities; opportunity alertness aptitudes; decision-making competencies and transition culture proficiencies. On the other hand, Succi \& Canovi (2019) considered analytical, reasoning, communication and interpersonal skills as the important determinants. Likewise, Boahin \& Hofman (2013) observed that communication, interpersonal skills, problem solving, adaptability, creativeness, decision-making and teamwork are the determinants in improving graduates' employability competencies.

\section{Research Design and Methods}

This section explores and explains the different methods used to collect and analyses the data collected for the study and embodies the objectives, the targeted population, sampling plan, the research instruments, and the questionnaire design for collecting the data. The main objective of the study is to demonstrate the importance of soft skills during Work Placement among the undergraduate students at UTM. Hence, 102 data had been collected through a well-structured online questionnaire which was developed to meet the aim of the study. All the questions were closed-ended except the quantitative questions. The questionnaires included questions on various aspects of Work Placement before and after the internship. A five-point Likert scale measured the opinions and attitudes of the students towards Work Placement. Learners were also given the chance to address questions in their own words one open-ended question at the end, giving them a stronger insight of their emotions, experiences and suggestions for future improvement about the Work Placement. Data were collected from the different schools of the University.

Reliability scores of the determinants were investigated using the alpha coefficient for learners before and after ratings, which were accepted as shown below in table 3.1.

Table 3.1: Before and After Work Placement Reliability Coefficients of Student Survey

Scales

Communication Skills (5 items)

Engagement Initiative (4 items)

Engagement Teamwork ( 2 items)

Analytical Skills (5 items)

Leadership Skills (4 items)
Before

0.943

0.928

0.878

0.965

0.957
After

0.881

0.923

0.892

0.935

0.924 


\section{(Source: Self)}

Although lower thresholds are sometimes used in research, a reliability coefficient of 0.70 is deemed appropriate (Nunnaly, 1978). However, reliability coefficients between 0.80 and 0.90 are typically preferred. Data analysis was performed using the SPSS version 22 and inferential analysis such as means, standard deviations, and frequencies of scores were investigated on every dimension (Communication skills, Engagement-initiative, Engagement-teamwork, Analytical Skills, and Leadership skills) and for each component. A mean score was calculated for each element indicated on the five-point scale before and after Work Placement. When screening for normality, skewness and kurtosis were used to examine the characteristics of the data. Correlations were also performed before and after the Work Placement on all dimensions.

\section{Result and Discussion}

The focal purpose of this section is to be able to analyses the data collected and draw meaningful conclusions about the study. It will help to derive meaningful information and knowledge used in improving and making informed decisions.

\subsection{Demographics Profiles}

Pie charts, bar charts and percentages have been used to depict the students' profiles.

\subsubsection{Demographics Profile of Students}

As shown in figure 1, the students who responded to the survey consisted of $42 \%$ male students and $58 \%$ female students. Further, shown in figure 2, 51\% of the students did their work placement in Ministries, 39.2\% in Private firms, 8.8\% in Parastatal bodies and the remaining 1\% in NGOs. 


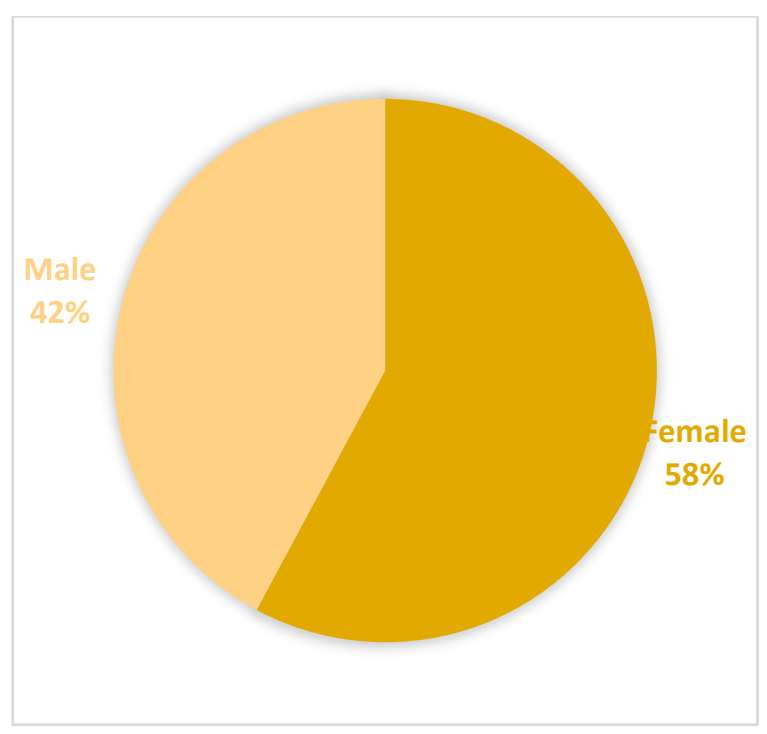

Figure 1: Gender

(Source: Self)

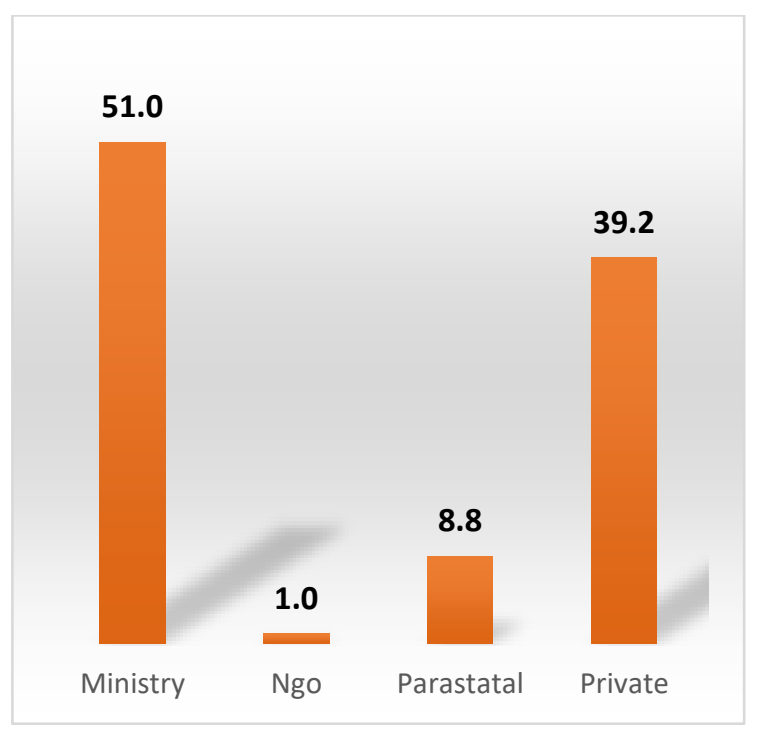

Figure 2: Type of organization

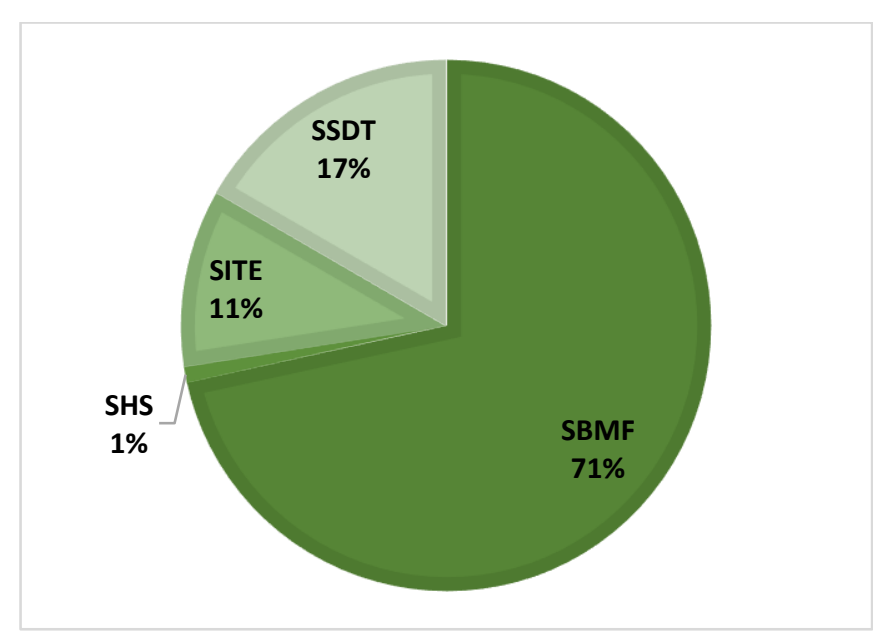

Figure 3: Schools

(Source: Self)

Figure 3 depicts that the majority of the students belonged to SBMF (71\%), followed by SSDT (17\%), SITE (11\%) and SHS (1\%). The students who responded to the survey were mostly from year 2 semester 2 and their field of study in the schools SBMF, SSDT, SITE and SHS are illustrated in figures 4-7 respectively. 


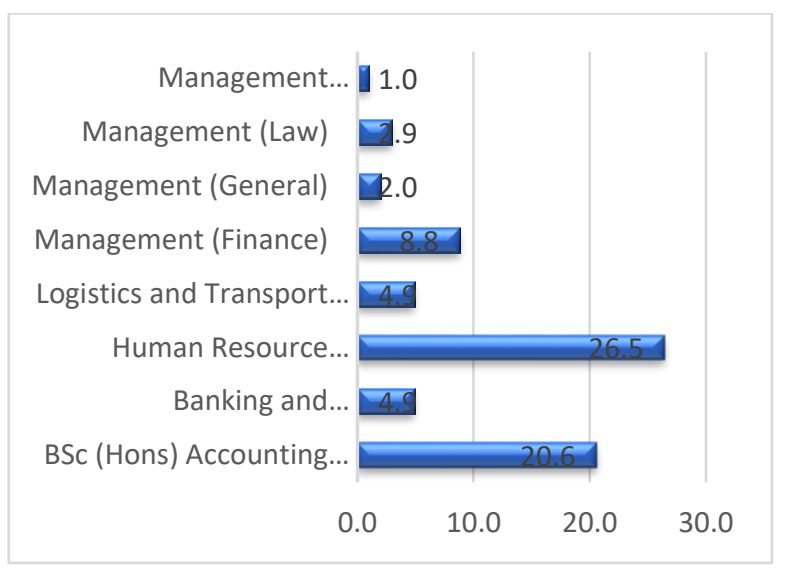

Figure 4: $S B M F$

(Source: Self)

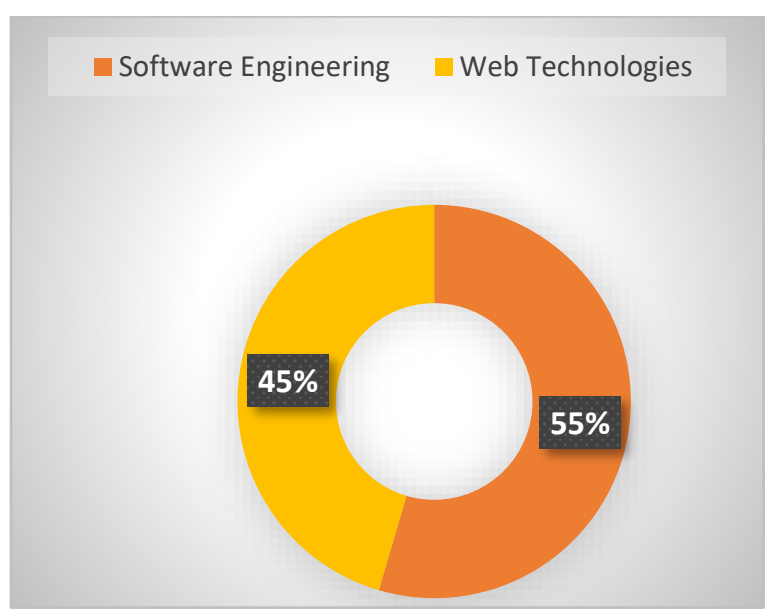

Figure 6: SITE

(Source: Self)

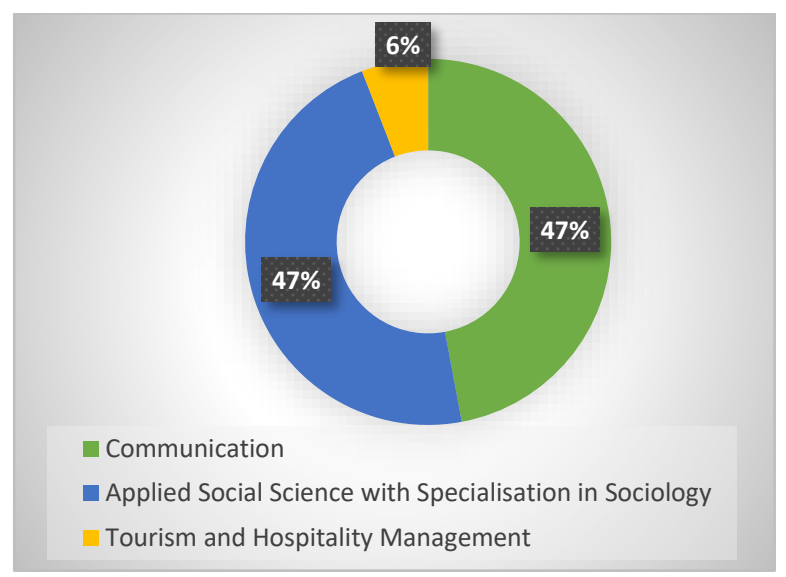

Figure 5: SSDT

(Source: Self)

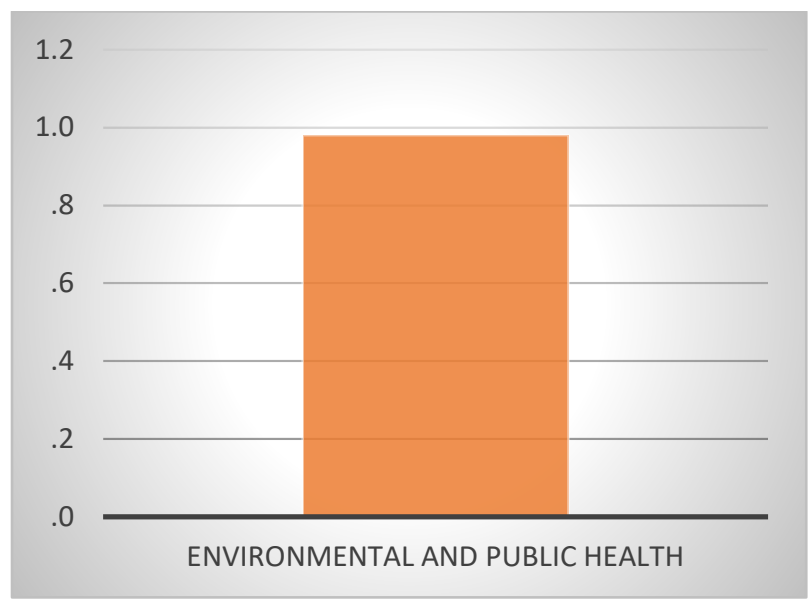

Figure 7: $S H S$

(Source: Self)

It was also noted that most of the students who took part in the survey thought the Work Placement was relevant to them. (94\%), whereas 6\% did not find the Work Placement relevant to them. 




Figure 8: Relevance of Work Placement

(Source: Self)

Figure 9 describes that $91 \%$ of students agreed that they got relevant skills and knowledge through the placement and 9\% disagreed with the statement. Similarly, 85\% of students agreed that the placement help them to decide their future preferred job whereas $15 \%$ did not agree with the statement (Figure 10).

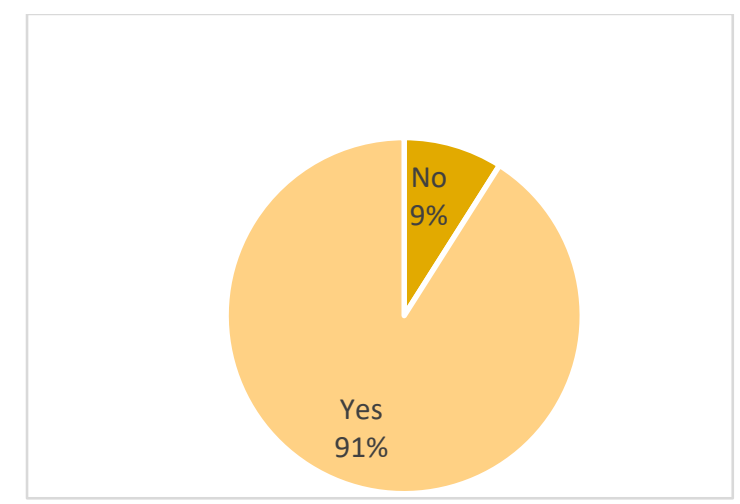

Figure 9: Relevant skills and knowledge

(Source: Self)

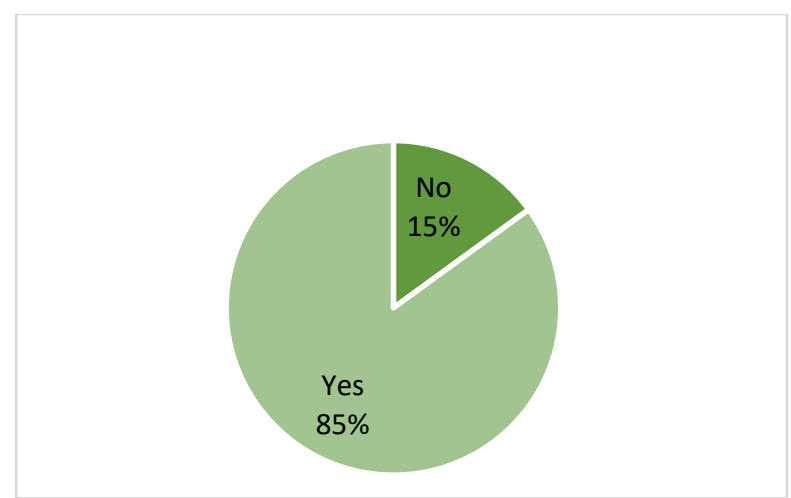

Figure 10: Help to decide their future

(Source: Self)

Figure11 examines students' clarity regarding academic goals and it is found that the majority of the students disagreed with the statement before their internship. On the other hand, after completing their Work Placement the majority of the students agreed that they had clarity regarding their academic goals. Figure 12 identifies the student's strengths related to academic goals for both pre and post Work Placement. The results reflected that the majority of the students gained personal strengths related to their academic goals after completing their internships. 
Table 4.1: Descriptive and inferential statistics pre and post-work placement scores related to their academic goals

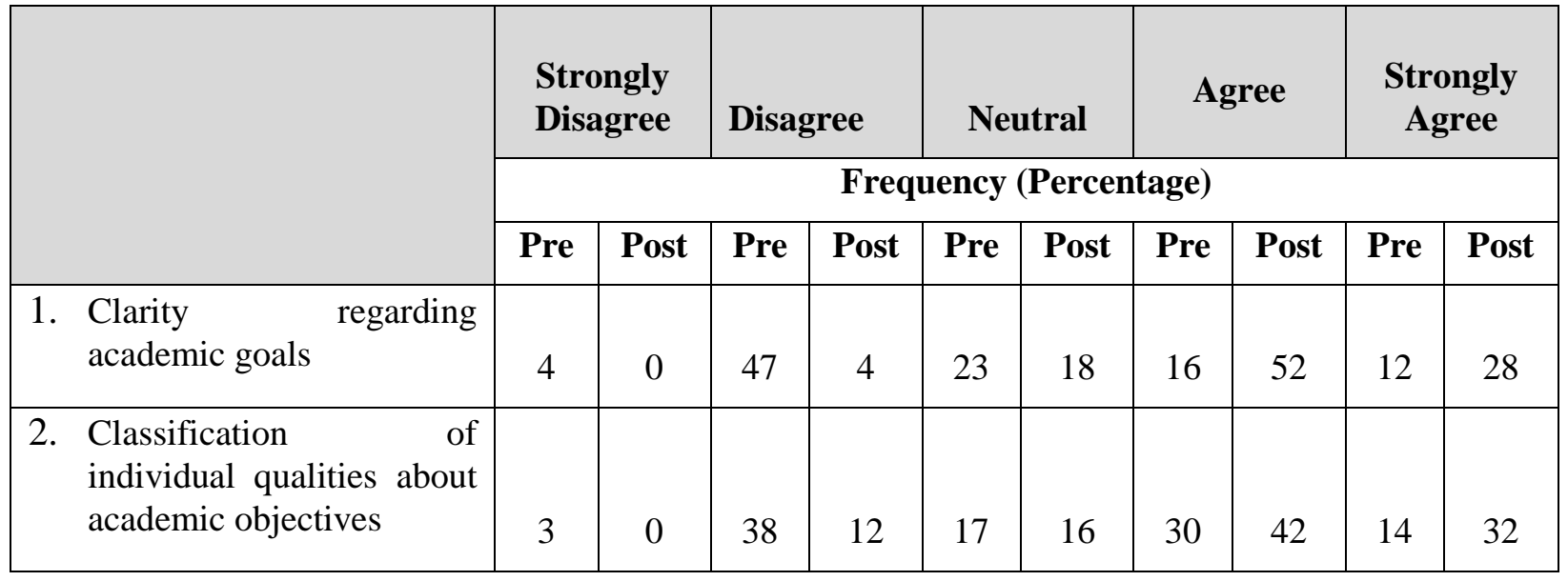

(Source: Self)



Figure 11: Awareness relating to academic objectives

(Source: Self)

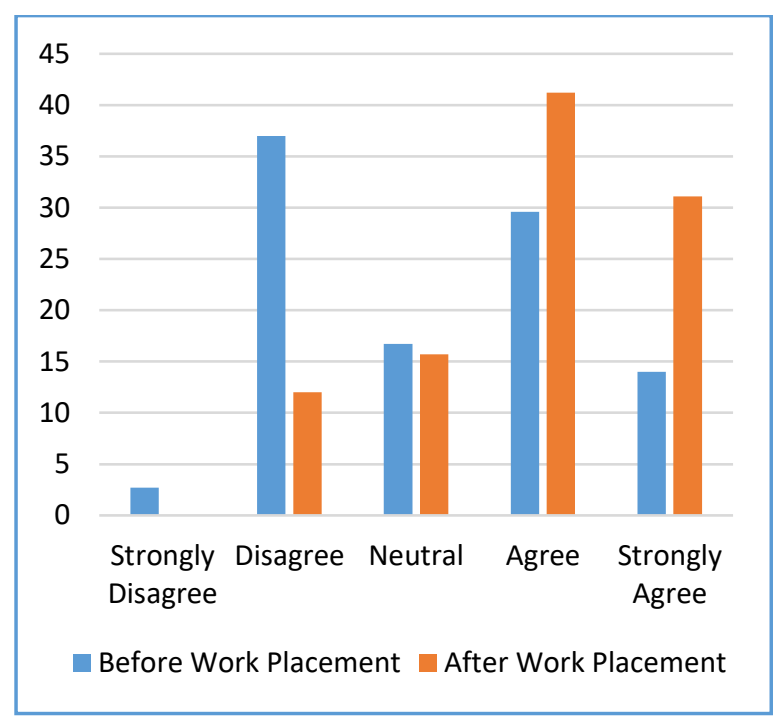

Figure 12: Personality traits about academic

objectives

(Source: Self)

Figure 13 shows that the vast majority of learners agreed that they were able to identify their weaknesses related to academic goals after completing their Work Placement. 


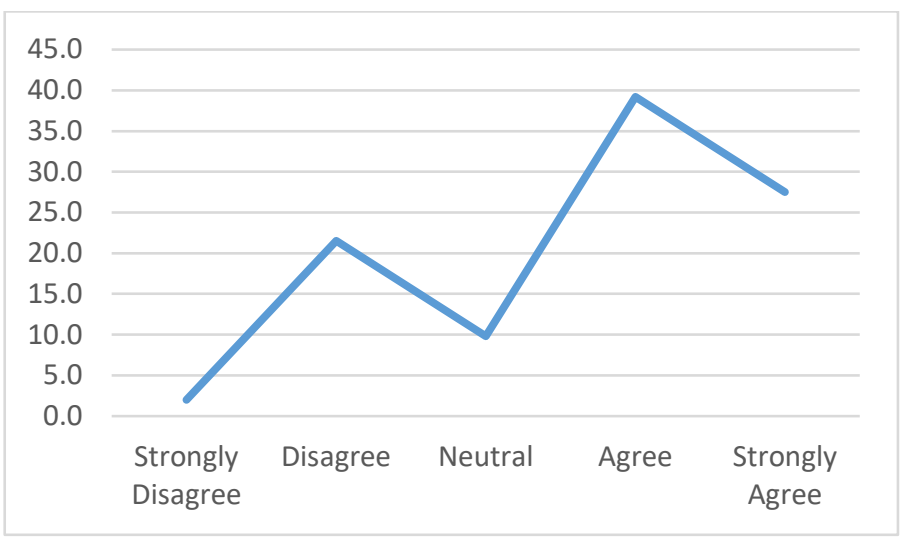

Figure 13: Personal flaws associated with academic goals being characterized.

(Source: Self)

\subsubsection{Level of Knowledge and Competencies Pre And Post the Students Complete Their Work Placement.}

Five soft skills scales namely Communication skills, Engagement Initiative, Engagement Teamwork, Analytical skills and Leadership skills measure knowledge and abilities of the learners before and after completing their Work Placement. The level of students' skills and abilities was assessed with a 7-item scale anchored on a 5-point rating system $(1=$ strongly disagree and $5=$ strongly agree). It could thus be observed that students overall had a positive attitude toward the acquired skills and abilities through Work Placement. A comparative analysis below shows the skills and abilities of the students before and after the Work Placement.

Table 4.2: Skills and abilities before work placement

\begin{tabular}{|c|c|c|c|c|c|}
\hline \multirow[t]{2}{*}{ Communication Skills } & $\begin{array}{l}\text { Strongly } \\
\text { Disagree }\end{array}$ & Disagree & Neutral & Agree & $\begin{array}{l}\text { Strongly } \\
\text { Agree }\end{array}$ \\
\hline & \multicolumn{5}{|c|}{ Frequency (Percentage) } \\
\hline $\begin{array}{l}\text { Communicating With The Person } \\
\text { In Charge }\end{array}$ & 2.0 & 21.6 & 14.7 & 41.2 & 20.6 \\
\hline $\begin{array}{l}\text { Expressing Ideas And Concepts } \\
\text { Clearly }\end{array}$ & 2.9 & 25.5 & 19.6 & 36.3 & 15.7 \\
\hline Listening Intently & 2.9 & 17.6 & 13.7 & 47.1 & 18.6 \\
\hline Communicating Well Orally & 2.9 & 22.5 & 11.8 & 43.1 & 19.6 \\
\hline Communicating Well In Writing & 3.9 & 17.6 & 11.8 & 45.1 & 21.6 \\
\hline \multirow[t]{2}{*}{ Engagement Initiative } & $\begin{array}{l}\text { Strongly } \\
\text { Disagree }\end{array}$ & Disagree & Neutral & Agree & $\begin{array}{l}\text { Strongly } \\
\text { Agree }\end{array}$ \\
\hline & \multicolumn{5}{|c|}{ Frequency (Percentage) } \\
\hline
\end{tabular}




\begin{tabular}{|c|c|c|c|c|c|}
\hline Adhering With The Deadlines & 2.9 & 19.6 & 13.7 & 43.1 & 20.6 \\
\hline $\begin{array}{l}\text { Approaching A Problem } \\
\text { Independently }\end{array}$ & 2.9 & 27.5 & 9.8 & 44.1 & 15.7 \\
\hline Understanding Own Personal Ethics & 2.9 & 19.6 & 8.8 & 49.0 & 19.6 \\
\hline $\begin{array}{l}\text { An Interest In Learning More In The } \\
\text { Relevant Field }\end{array}$ & 1.0 & 21.6 & 15.7 & 38.2 & 23.5 \\
\hline \multirow[t]{2}{*}{ Engagement Teamwork } & $\begin{array}{l}\text { Strongly } \\
\text { Disagree }\end{array}$ & Disagree & Neutral & Agree & $\begin{array}{c}\text { Strongly } \\
\text { Agree }\end{array}$ \\
\hline & \multicolumn{5}{|c|}{ Frequency (Percentage) } \\
\hline Make Good Usage Reviews & 3.9 & 19.6 & 10.8 & 40.2 & 25.5 \\
\hline I Help Others To Learn & 2.0 & 18.6 & 12.7 & 42.2 & 24.5 \\
\hline \multirow[t]{2}{*}{ Analytical Skills } & $\begin{array}{l}\text { Strongly } \\
\text { Disagree }\end{array}$ & Disagree & Neutral & Agree & $\begin{array}{l}\text { Strongly } \\
\text { Agree }\end{array}$ \\
\hline & \multicolumn{5}{|c|}{ Frequency (Percentage) } \\
\hline $\begin{array}{l}\text { Determining The Capabilities And } \\
\text { Expertise Required To Accomplish A } \\
\text { Project (E.G. Technology, } \\
\text { Communications And Research) }\end{array}$ & 2.9 & 20.6 & 12.7 & 40.2 & 23.5 \\
\hline Interpreting Information & 2.9 & 20.6 & 5.9 & 50.0 & 20.6 \\
\hline Summarizing What I Have Learned & 1.0 & 21.6 & 9.8 & 48.0 & 19.6 \\
\hline Retaining New Ideas & 1.0 & 21.6 & 10.8 & 42.2 & 24.5 \\
\hline Recommending Solutions & 4.9 & 21.6 & 11.8 & 40.2 & 21.6 \\
\hline \multirow[t]{2}{*}{ Leadership Competencies } & $\begin{array}{l}\text { Strongly } \\
\text { Disagree }\end{array}$ & Disagree & Neutral & Agree & $\begin{array}{c}\text { Strongly } \\
\text { Agree }\end{array}$ \\
\hline & \multicolumn{5}{|c|}{ Frequency (Percentage) } \\
\hline $\begin{array}{l}\text { Exerting A High Level Of Effort And } \\
\text { Persevering Toward Goal Attainment }\end{array}$ & 2.0 & 21.6 & 13.7 & 48.0 & 14.7 \\
\hline $\begin{array}{l}\text { Believing In My Self-Worth And } \\
\text { Maintaining A Positive View Of } \\
\text { Myself }\end{array}$ & 2.9 & 16.7 & 14.7 & 47.1 & 18.6 \\
\hline Choosing Ethical Courses Of Action & 2.0 & 24.5 & 8.8 & 43.1 & 21.6 \\
\hline Persuading And Convincing Others & 2.0 & 25.5 & 14.7 & 43.1 & 14.7 \\
\hline
\end{tabular}

(Source: Self)

Table 4.3: Skills and abilities after a work placement 


\begin{tabular}{|c|c|c|c|c|c|}
\hline \multirow[t]{2}{*}{ Communication Skills } & $\begin{array}{l}\text { Strongly } \\
\text { Disagree }\end{array}$ & Disagree & Neutral & Agree & $\begin{array}{c}\text { Strongly } \\
\text { Agree }\end{array}$ \\
\hline & \multicolumn{5}{|c|}{ Frequency (Percentage) } \\
\hline $\begin{array}{l}\text { Communicating With The Person In } \\
\text { Charge }\end{array}$ & 2.0 & 16.7 & 18.6 & 43.1 & 19.6 \\
\hline $\begin{array}{l}\text { Expressing Ideas And Concepts } \\
\text { Clearly }\end{array}$ & 2.9 & 19.6 & 13.7 & 38.2 & 25.5 \\
\hline Listening Intently & 2.0 & 21.6 & 9.8 & 39.2 & 27.5 \\
\hline Communicating Well Orally & 0.0 & 0.0 & 5.9 & 49.0 & 45.1 \\
\hline Communicating Well In Writing & 0.0 & 0.0 & 11.8 & 49.0 & 39.2 \\
\hline \multirow[t]{2}{*}{ Engagement Initiative } & $\begin{array}{l}\text { Strongly } \\
\text { Disagree }\end{array}$ & Disagree & Neutral & Agree & $\begin{array}{l}\text { Strongly } \\
\text { Agree }\end{array}$ \\
\hline & \multicolumn{5}{|c|}{ Frequency (Percentage) } \\
\hline Adhering With The Deadlines & 0.0 & 0.0 & 14.7 & 40.2 & 45.1 \\
\hline Approaching A Problem Independently & 0.0 & 0.0 & 10.8 & 52.9 & 36.3 \\
\hline Understanding Own Personal Ethics & 0.0 & 0.0 & 10.5 & 50.0 & 39.2 \\
\hline $\begin{array}{l}\text { An Interest In Learning More In The } \\
\text { Relevant Field }\end{array}$ & 0.0 & 1.0 & 11.8 & 40.2 & 47.1 \\
\hline \multirow[t]{2}{*}{ Engagement Teamwork } & $\begin{array}{l}\text { Strongly } \\
\text { Disagree }\end{array}$ & Disagree & Neutral & Agree & $\begin{array}{c}\text { Strongly } \\
\text { Agree }\end{array}$ \\
\hline & \multicolumn{5}{|c|}{ Frequency (Percentage) } \\
\hline Make Good Usage Reviews & 0.0 & 0.0 & 11.8 & 50.0 & 38.2 \\
\hline I Help Others To Learn & 0.0 & 1.0 & 11.8 & 51.0 & 36.3 \\
\hline \multirow[t]{2}{*}{ Analytical Skills } & $\begin{array}{l}\text { Strongly } \\
\text { Disagree }\end{array}$ & Disagree & Neutral & Agree & $\begin{array}{l}\text { Strongly } \\
\text { Agree }\end{array}$ \\
\hline & \multicolumn{5}{|c|}{ Frequency (Percentage) } \\
\hline $\begin{array}{l}\text { Determining The Capabilities And } \\
\text { Expertise Required To Accomplish A } \\
\text { Project (E.G. Technology, } \\
\text { Communications And Research) }\end{array}$ & 0.0 & 1.0 & 19.6 & 47.1 & 32.4 \\
\hline Interpreting Information & 0.0 & 0.0 & 15.7 & 55.9 & 28.4 \\
\hline Summarizing What I Have Learned & 0.0 & 0.0 & 16.7 & 51.0 & 32.4 \\
\hline Retaining New Ideas & 1.0 & 0.0 & 13.7 & 52.0 & 33.3 \\
\hline Recommending Solutions & 0.0 & 2.0 & 13.7 & 50.0 & 34.3 \\
\hline \multirow[t]{2}{*}{ Leadership Competencies } & $\begin{array}{l}\text { Strongly } \\
\text { Disagree }\end{array}$ & Disagree & Neutral & Agree & $\begin{array}{l}\text { Strongly } \\
\text { Agree }\end{array}$ \\
\hline & \multicolumn{5}{|c|}{ Frequency (Percentage) } \\
\hline $\begin{array}{l}\text { Exerting A High Level Of Effort And } \\
\text { Persevering Toward Goal Attainment }\end{array}$ & 0.0 & 0.0 & 9.8 & 52.0 & 38.2 \\
\hline
\end{tabular}




\begin{tabular}{|l|l|l|l|l|l|}
\hline $\begin{array}{l}\text { Believing In My Self-Worth And } \\
\text { Maintaining A Positive View Of } \\
\text { Myself }\end{array}$ & 0.0 & 0.0 & 8.8 & 47.1 & 44.1 \\
\hline Choosing Ethical Courses Of Action & 0.0 & 0.0 & 7.8 & 53.9 & 38.2 \\
\hline Persuading And Convincing Others & 0.0 & 2.0 & 8.8 & 52.0 & 37.3 \\
\hline
\end{tabular}

(Source: Self)

\begin{tabular}{|c|c|}
\hline \multicolumn{2}{|c|}{ Communication Skills } \\
\hline 口 After workplacement $\quad$ Before workplacement & 口 After workplacement Before workplacement \\
\hline \begin{tabular}{l|l} 
& 19.6 \\
Strongly Agree & 20.6
\end{tabular} & $\begin{array}{ll} & 25.5\end{array}$ \\
\hline Agree $\quad 41.2$ & Agree 36.3 \\
\hline $\begin{array}{ll}\text { Neutral } & 14.7 .6\end{array}$ & $\begin{array}{ll}\text { Neutral } & 13.7 \\
19.6\end{array}$ \\
\hline $\begin{array}{ll}\text { Disagree } & 16.7 \\
21.6\end{array}$ & $\begin{array}{ll}\text { Disagree } & 19.6 \\
25.5\end{array}$ \\
\hline Strongly Disagree $=2.0$ & Strongly Disagree $\quad \begin{array}{r}2.9 \\
2.9\end{array}$ \\
\hline Figure 14: Communicating With The Person & Figure 15: Communicating Ideas And \\
\hline In Charge & Concepts Clearly \\
\hline (Source: Self) & (Source: Self) \\
\hline - After workplacement $\quad$ Before workplacement & After workplacement $\quad$ Before workplacement \\
\hline Strongly Agree 18.627 .5 & Strongly Agree \\
\hline Agree & Agree $\square$ \\
\hline 9.83 .7 & Neutral $\quad 5,911.8$ \\
\hline Disagree $\quad \overbrace{17.6}$ & Disagree $\quad$ L 0.0 17.6 \\
\hline Strongly Disagree $\quad \mathbf{3} 2.9$ & Strongly Disagree $\quad$ S.९.9 \\
\hline $\begin{array}{c}\text { Figure 16: Listening Intently } \\
\text { (Source: Self) }\end{array}$ & $\begin{array}{c}\text { Figure 17: Communicating Well Orally } \\
\text { (Source: Self) }\end{array}$ \\
\hline
\end{tabular}




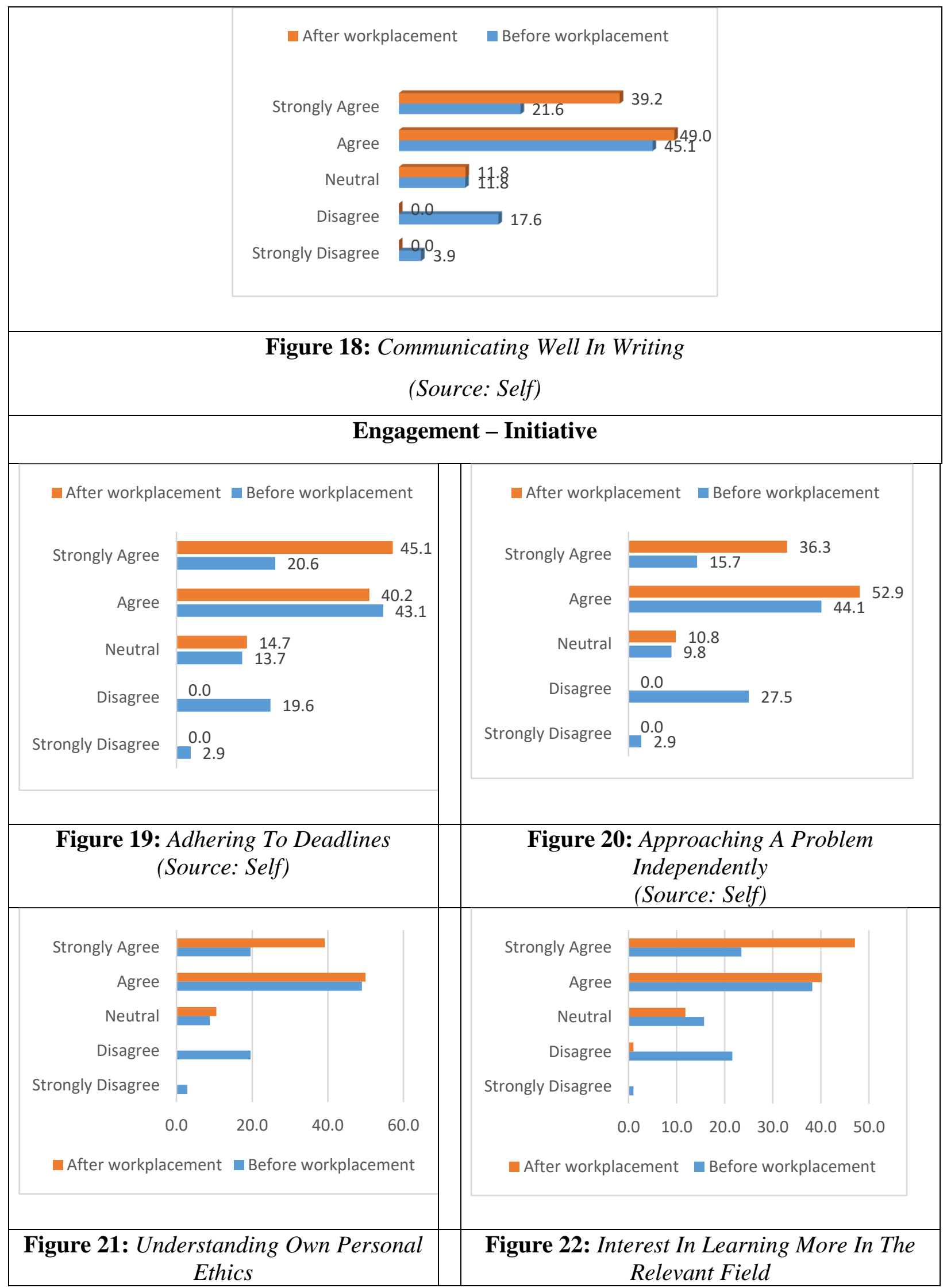









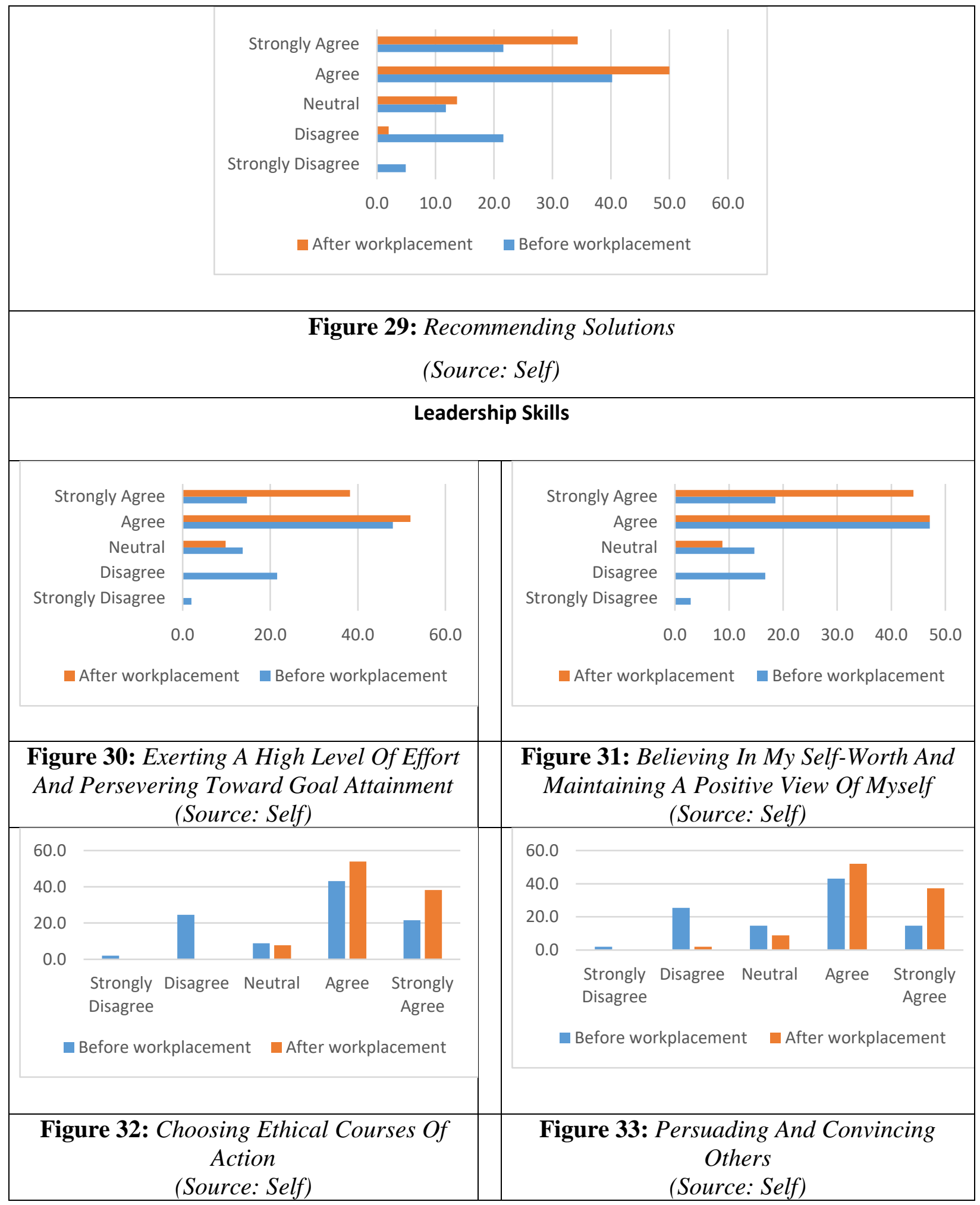

At a macro level of the exploratory data analysis, a mean score for each item represented on the five scales (communication, initiative, teamwork, analytical skills and leadership skills) was 
detailed for prior and after Work Placement. When screening for normality, skewness and kurtosis were used to examine the dimension of, the data (see Table 4.4).

Hair et al. (2010) and Byrne (2010) asserted that the result is considered normal if the skewness is between 2 and +2 , and George and Mallery (2010) argue that kurtosis values between -2 and +2 are acceptable to confirm a normal univariate distribution. As a result, it is founded that the resultant data the normal distribution specifications eventually all the learners' information have been included in research findings.

Table 4.4: Learners' Survey of Soft-Skill Improvement Statistical Analysis for Prior and After

Work Placement Scores

\begin{tabular}{|l|l|l|l|l|l|l|l|l|}
\hline \multirow{2}{*}{ Scales } & \multicolumn{3}{|c|}{ Prior Work Placement } & \multicolumn{4}{c|}{ After Work Placement } \\
\cline { 2 - 10 } & Mean & StdDev & Skewness & $\begin{array}{c}\text { Kurtosis } \\
\text { Stats }\end{array}$ & Mean & StdDev & Skewness & $\begin{array}{c}\text { Kurtosis } \\
\text { Stats }\end{array}$ \\
\hline Comm & 3.54 & 1.00 & -0.52 & -0.52 & 4.33 & 0.55 & -0.62 & -0.03 \\
\hline Intia & 3.56 & 1.00 & -0.68 & -0.60 & 4.29 & 0.62 & -0.38 & -0.74 \\
\hline Twork & 3.66 & 1.07 & -0.53 & -0.83 & 4.25 & 0.64 & -0.32 & -0.58 \\
\hline Analyst & 3.62 & 1.05 & -0.58 & -0.72 & 4.15 & 0.63 & -0.21 & -0.70 \\
\hline Leadership & 3.54 & 1.02 & -0.59 & -0.61 & 4.30 & 0.58 & -0.37 & -0.50 \\
\hline
\end{tabular}

(Source: Self)

Correlations were also performed across all dimensions for student responses before and following the Work Placement. As expected, all five scales are highly correlated. The positive coefficients indicate that a change in one scale Work Placement influences the value of the other scale. (See Tables 4.5 and 4.6).

Table 4.5: Student Survey before the Work Placement Dimensional Correlation

\begin{tabular}{|l|c|c|c|c|c|}
\hline & Comm & Intia & Twork & Analyst & Leadership \\
\hline Comm & - & & & & \\
\hline Intia & $0.662^{* *}$ & - & & & \\
\hline Twork & $0.616^{* *}$ & $0.830^{* *}$ & - & & \\
\hline Analyst & $0.668^{* *}$ & $0.853^{* *}$ & $0.818^{* *}$ & - & \\
\hline Ldership & $0.631^{* *}$ & $0.869^{* *}$ & $0.796^{* *}$ & $0.645^{* *}$ & - \\
\hline
\end{tabular}

(Source: Self)

Table 4.6: Student Survey following the Work Placement Dimensional Correlation

\begin{tabular}{|l|c|c|c|c|c|}
\hline & Comm & Intia & Twork & Analyst & Leadership \\
\hline Comm & - & & & & \\
\hline Intia & $0.809^{* *}$ & - & & & \\
\hline Twork & $0.974^{* *}$ & $0.894^{* *}$ & - & & \\
\hline Analyst & $0.833^{* *}$ & $0.884^{* *}$ & $0.908^{* *}$ & - & \\
\hline Ldership & $0.836^{* *}$ & $0.927^{* *}$ & $0.693^{* *}$ & $0.928^{* *}$ & - \\
\hline
\end{tabular}

(Source: Self) 


\subsection{Discussion}

The study's goal was to determine whether students were able to develop, the skills that occurred because of their internship, which included communication, teamwork, initiative, analytical thinking and leadership. The respondent results illustrated that engagement in a traineeship enhanced soft skills on all dimensions observed. Work placement entails practicing skills, facing problems, and seeking to apply them appropriately after reflecting on how the learner handled situations. The study's findings supported the role of apprenticeships as a learning strategy for learner soft-skill improvement.

\section{Conclusion}

This study backs up the importance of Work Placement in skills development and enhancement, not as a substitute for existing on-campus education, but as a complement to it. Work placement expands on the skills learned in educational settings by increasing learner knowledge and competence in skill usage under the guidance of a place of work supervisor. Students, as in past findings, recognized the advantages of Work Placement as prospects to perform and improve skills in a realistic setting, as well as collaborate with practitioners to develop a deeper understanding of their profession's duties and responsibilities, expectations, and objectives. Students' problems may relate to deficiencies in placement along with course speciality, organization, and strategy. As a result, while this study clearly shows that internships are essential to our country's economic development, it also emphasizes the importance of improving both components of an effective placement and undergraduate courses that produce and guide learners during their traineeship adventure.

The study recommends work placements as a teaching method to develop student soft skills based on survey results. Surveys have been used because there was no quantitative research evidence to back soft-skill improvement through traineeships, however, a descriptive interpretation could provide perspective for learner and supervisor feedback and understanding of the specific observations. The current study was the first to demonstrate the importance of soft skills during internships. One limitation faced by the current research was that the sample was quite small since the study was centred only on the limited number of undergraduate students who are studying at UTM. A bigger sample would have strengthened the validity of the findings.

Further investigation of some of the results of this study will help supervisors and students who have completed their placement to better understand the effectiveness of Work Placement. 
Students who have completed their internship can be part of future research studies. In addition, attaching a Theoretical Framework will attempt to strengthen the arguments in the current study.

\section{REFERENCES}

Billett, S. (2009). Realising the educational worth of integrating work experiences in higher education. Studies in Higher Education, 34(7), 827-843. https://doi.org/10.1080/03075070802706561

Boahin, P., and Hofman, A. (2013). A disciplinary perspective of competency-based training on the acquisition of employability skills. Journal of Vocational Education \&Training, 65(3), 385-401. https://doi.org/10.1080/13636820.2013.834954

Byrne B. M. (2010). Structural equation modeling with AMOS: Basic concepts, applications, and programming (2nd ed). New York, NY: Routledge. (Accessed 29 April 2020).

Business Magazine. (2016). "Business Magazine \& Verde Frontier Employability Survey", available at: http://www.verdefrontier.mu/images/BMagArticle on employability 270716.pdf (Accessed 29 April 2020).

Choy, S., and Delahaye, B. (2011). Partnerships between universities and workplaces: some challenges for work-integrated learning. Studies in Continuing Education, 33(2), $157-$ 172. https://doi.org/10.1080/0158037X.2010.546079

George, D., and Mallery, M. (2010). SPSS for Windows Step by Step: A Simple Guide and Reference, 17.0 update (10a Ed.) Boston: Pearson.

Hair, J. F., Black, W. C., Babin, B. J., and Anderson, R. E. (2010). Multivariate data analysis: A global perspective (7th ed.). Upper Saddle River, NJ: Pearson Prentice Hall. https://doi.org/10.1016/j.jmva.2009.12.014

Jackson, D. and Wilton, N. (2017). "Perceived employability among undergraduates and the importance of career self-management, work experience and individual characteristics", Higher Education Research and Development, Vol. 36 No. 4, pp. 747-762. https://doi.org/10.1080/07294360.2016.1229270

Jackson, D. (2014). “Testing a Model of Undergraduate Competence in Employability Skills and Its Implications for Stakeholders.” Journal of Education \& Work 27 (2): 220-242. https://doi.org/10.1080/13639080.2012.718750 
Jackson, D. (2015). Employability skill development in work-integrated learning: Barriers and best practice. Studies in Higher Education, 40(2), 350-367. https://doi.org/10.1080/03075079.2013.842221

Jorre De St Jorre, T. and Oliver, B. (2018). "Want students to engage? Contextualise graduate learning outcomes and assess for employability", Higher Education Research and Development, Vol. 37 No. 1, pp. 1-14. https://doi.org/10.1080/07294360.2017.1339183

Kramer, M. and Usher, A. (2011). Work-integrated learning and career-ready students: Examining the evidence. Toronto: Higher Education Strategy Associates.

Law, B. and Watts AG (2003). The dots analysis. Elsworth, England: The Career-Learning Network. (Accessed 26 April 2020).

Orrell, J (2011). Good practices report: work-integrated learning. Strawberry Hills, NSW: Australian Learning and Teaching Council.

Patrick, C., Peach, D., Pocknee, C., Webb, F., Fletcher, M., Pretto, G., (2009). The WIL (Work Integrated Learning) report: National Scoping Study. Queensland University of Technology, Brisbane (Accessed 26 February 2020).

Patrick, C., Peach, D., Pocknee, C., Webb, F., Fletcher, M., and Pretto, G. (2008). The WIL [work integrated learning] report: A national scoping study [Australian learning and teaching council (ALTC) final report]. Brisbane: Queensland University of Technology.

Smith, C. and Worsfold, K. (2015). Unpacking the learning-work nexus: 'priming' as lever for high-quality learning outcomes in work-integrated learning curricula. Studies in Higher Education, 40(1): 22-42. https://doi.org/10.1080/03075079.2013.806456

Smith, C., Ferns, S., Russell, L. and Cretchley, P. (2014). The Impact of Work Integrate Learning on Student Work- Readiness. Sydney: Office for Learning and Teaching.

Smith, C. (2012). Evaluating the quality of work-integrated learning curricula: A comprehensive framework. Higher Education Research and Development 31, no. 2: 247-62. https://doi.org/10.1080/07294360.2011.558072

Succi, C., and Canovi, M. (2019). Soft skills to enhance graduate employability: comparing students and employers' perceptions. Studies in Higher Education, 1-14. https://doi.org/10.1080/03075079.2019.1585420 
Taylor, S. and Govender, C.M. (2017). Increasing employability by implementing a WorkIntegrated Learning partnership model in South Africa: a student perspective. Africa Education Review, 14(1):105-119. https://doi.org/10.1080/18146627.2016.1224585

Tran, L. T., and Soejatminah, S. (2016). "Get foot in the door”: International students' Perceptions of work integrated learning. British Journal of Educational Studies, 64, 337355. https://doi.org/10.1080/00071005.2015.1128526

UNDESA Division for Sustainable Development. (2014). "Partnerships Briefs for Small Island Developing States - Sustainable Economic Development". (Accessed 30 April 2020).

Walker, M. and Fongwa, S. (2017). "Human development, capabilities and graduate employability”, Universities, Employability and Human Development, Palgrave Macmillan, London, pp. 215-227. https://doi.org/10.1057/978-1-137-58452-6 9

Watts, A.G. (2006). Career development learning and employability. York, England: The Higher Education Academy. (Accessed 30 April 2020). 